\title{
USE OF THE RANDOM SETTLING TECHNIQUE IN QUANTITATIVE STUDIES OF CALCAREOUS NANNOFOSSILS IN THE NW SOUTH ATLANTIC OCEAN
}

\author{
HELIANE BEVERVANSO FERRARESE, FELIPE ANTONIO DE LIMA TOLEDO, \\ JULIANA PEREIRA DE QUADROS \& KAREN BADARACO COSTA \\ Laboratório de Paleoceanografia do Atlântico Sul, LaPAS, Instituto Oceanográfico, USP, 191, 05508-900, São Paulo, \\ SP, Brasil.helianeferrarese@yahoo.com.br,felipe.toledo@io.usp.br,karen.costa@io.usp.br
}

\begin{abstract}
Paleoceanographic surveys can be performed from the quantitative study of calcareous nannofossils since variations in the nannoflora through time indicate a biotic response to environmental changes. In this study, two preparation techniques of calcareous nannofossils slides - the conventional smear slide and the random settling techniques - were compared in order to investigate which method is better in quantitative studies for paleoceanographic reconstructions. The adaptation of sample preparation methods allows studies of relative and absolute abundances of calcareous nannofossils. Although the random settling technique requires a much longer preparation time, it allows the calculation of the number of coccoliths per gram of sediment. This, together with the relative abundance and stable oxygen and carbon isotopic data allowed a more detailed analysis of paleotemperature and paleoproductivity. The Gephyrocapsa genus showed good correlations with $\delta^{18} \mathrm{O}$ and $\delta^{13} \mathrm{C}$, indicating an influence of temperature and nutrient availability on the abundance of this genus.
\end{abstract}

Key words: Calcareous nannofossils, quantitative studies, paleoceanography, preparation techniques.

\begin{abstract}
RESUMO - Levantamentos paleoceanográficos podem ser realizados a partir do estudo quantitativo de nanofósseis calcários, uma vez que alterações na composição da nanoflora, ao longo do tempo geológico, indicam uma resposta biótica às mudanças ambientais. No presente trabalho foram comparadas duas técnicas de preparação para nanofósseis calcários, a fim de se demonstrar qual a mais adequada para uso em estudos quantitativos em reconstruções paleoceanográficas. A adaptação de métodos de preparação de amostras permite comparar abundâncias relativas e absolutas em estudos de nanofósseis calcários. As técnicas utilizadas foram descritas anteriormente e diferem basicamente no tempo de preparação das lâminas e na precisão da análise quantitativa. A preparação de lâminas de nanofósseis calcários, a partir da técnica de decantação aleatória, permite o cálculo do número de cocolitos por grama de sedimento, e este, aliado às abundâncias relativas e dados isotópicos de oxigênio e carbono, possibilita uma análise mais detalhada da paleotemperatura e paleoprodutividade. O gênero Gephyrocapsa mostrou boas correlações com $\delta^{18} \mathrm{O}$ e $\delta^{13} \mathrm{C}$, indicando uma influência da temperatura e da disponibilidade de nutrientes na abundância deste gênero.
\end{abstract}

Palavras-chave: Nanofósseis calcários, estudos quantitativos, paleoceanografia, técnicas de preparação.

\section{INTRODUCTION}

Biogenic oozes are chiefly composed of calcareous or siliceous tests of marine organisms. For paleoclimatic studies, the most important calcareous materials are the tests of foraminifera and the much smaller tests, and/or tests fragments, of calcareous nannofossils informally known as coccoliths (Bradley, 1999).

Calcareous nannoplanktons are an important part of the phytoplankton in the marine realm and have been one of the major open-ocean primary producers since the Triassic. They are also the most productive carbonate-secreting organisms on earth (Baretta-Bekker et al., 1998). The coccoliths, minute calcified plates produced by haptophyte algae, are a major component of pelagic carbonates (Roth, 1994).
The distribution of calcareous nannoplankton is strongly influenced by climatic and oceanographic conditions. They are widespread throughout the oceans and are important indicators of oceanographic changes with different species being sensitive to climatic change and variations in nutrient contents (Mostajo, 1986; Roth, 1994; Flores \& Sierro, 1997; Henriksson, 2000; Herrle, 2003; Buccianti \& Esposito, 2004).

As a result of their extensive occurrence, great abundance in deep-sea sediments, rapid evolution and exclusively planktonic nature, calcareous nannofossils have been broadly employed in biostratigraphy (Young, 1991; Okada, 2000), geochemistry (Buccianti \& Esposito, 2004; Thierstein et al., 1977; Steinmetz, 1994), biogeography (Okada, 1992; Roth, 1994), and paleoceanography-paleoclimatology (Giraudeau, 1992; Beaufort et al., 1997; Toledo, 2000; Buccheri et al., 2002). 
In paleoenvironmental studies, quantitative analyses (absolute and relative abundances) as well as qualitative ones (assemblage composition) are of great significance. However, the long-term abundance fluctuations and rapid evolutionary rates of calcareous nannofossil are only evident when quantitative studies are performed.

Different species in various abundances characterize equatorial to subpolar regions (McIntyre \& Bé, 1967; Okada \& Honjo, 1973; Winter et al., 1994). Time-progressive variations in the composition of calcareous nannofossils indicate biological responses to environmental changes (Matsuaoka \& Okada, 1989). In order to estimate coccoliths abundance in sediments and identify fossil associations, conventional counting methods are employed (Okada, 1983; Okada, 1992).

The aim of the present study is to make a quantitative study of calcareous nannofossils in the NW South Atlantic Ocean by using the random settling technique in order to observe paleoceanographical changes in the last $30 \mathrm{kyr}$.

The traditional techniques of slide preparation only allow an assessment of the relative abundance of calcareous nannofossil's species. Relative abundance gives a good indication of the general assemblage character, but percentage data could mask inherent species-by-species variations. This technique has been broadly employed in Brazilian studies.

Conversely, Flores \& Sierro (1997) proposed a random settling technique. This is a rapid and easy method to obtain slides on which the coccoliths are evenly distributed, and presents a possibility of standardizing the procedure and producing large series of samples in order to save time.

Random settling technique also allows estimating coccolith absolute abundances in number of coccolith specimens per gram of sediments, by converting the amount of calcareous nannofossils into nannofossil fluxes when precise age models and sediment densities are available (Flores \& Sierro, 1997; Ferreira \& Cachão, 2003).

\section{MATERIAL AND METHODS}

Sixteen deep-sea sediment samples (sample intervals of $10 \mathrm{~cm}$ ) from one high-resolution piston-core (ESP-8)

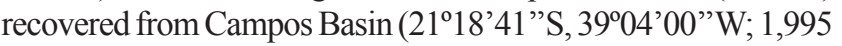
$\mathrm{m}$ water depth; Figure 1) were prepared by the random settling technique.

The chronological framework of the core was based on the correlation of the oxygen isotopic record of benthic foraminifers with the SPECMAP chronology of Martinson et al. (1987), as well as Accelerator Mass Spectrometer radiocarbon datings based on two samples of monospecific planktonic foraminifer Globigerinoides ruber (Table 1). The data were compared with the oxygen and carbon isotope record (Toledo, 2000).

\section{Procedures (after Flores \& Sierro, 1997)}

A total of $0.100 \mathrm{~g}$ of dried sediments were weighed using a microbalance (Digimed KN500). The materials were diluted

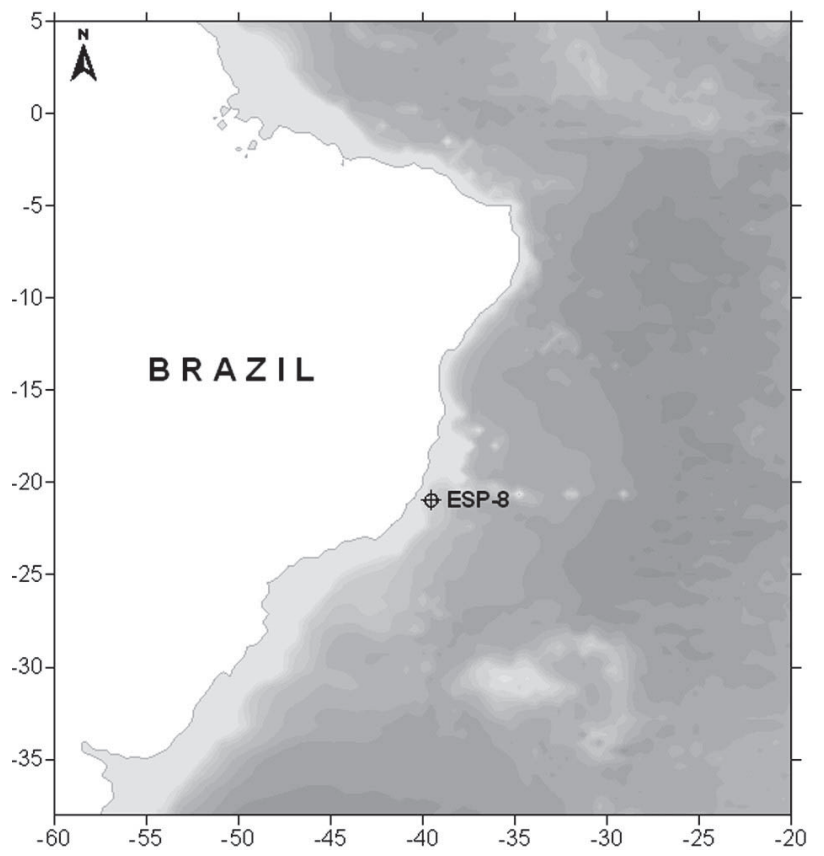

Figure 1. Location map of Core ESP-8.

in $10 \mathrm{ml}$ buffering water $\left(0.2 \mathrm{~g} \mathrm{NaHCO}_{3}, 0.15 \mathrm{~g} \mathrm{Na}_{2} \mathrm{CO}_{3}\right.$ and $0.08 \mathrm{~g}$ of unflavoured gelatine "Gold Gelatine" per litter of distilled water). The gelatine was added to the solution to reduce natural surface tension. After the mixture had been vigorously shaken and then left to settle for three minutes, the upper solution was dropped onto a settling device (nannodrome) which includes a coverslide $(4 \mathrm{~cm} \times 2.5 \mathrm{~cm})$ previously placed on the bottom of a Petri dish $\left(25.518 \mathrm{~cm}^{2}\right)$. The mixture was kept on a stable, horizontal surface under room temperature settling for at least 12 hours. After this time the fine fraction completely deposited and the water was drained carefully using short strips of filter paper. Then the disk was transferred to a heater at a temperature of about $60^{\circ} \mathrm{C}$. When the disk dried a coverslide was mounted with Canada balsam.

Table 1. ESP-8 chronology.

\begin{tabular}{c|c}
\hline Depth (cm) & Age (kyr) \\
\hline 0 & 0.21 \\
7 & 2.48 \\
13 & 4.38 \\
19 & 6.28 \\
25 & 8.18 \\
31 & 10.08 \\
37 & 11.98 \\
45 & 14.51 \\
51 & 16.41 \\
57 & 18.31 \\
64 & 20.42 \\
70 & 22.23 \\
76 & 24.03 \\
82 & 25.84 \\
89 & 27.95 \\
99 & 29.98 \\
\hline
\end{tabular}



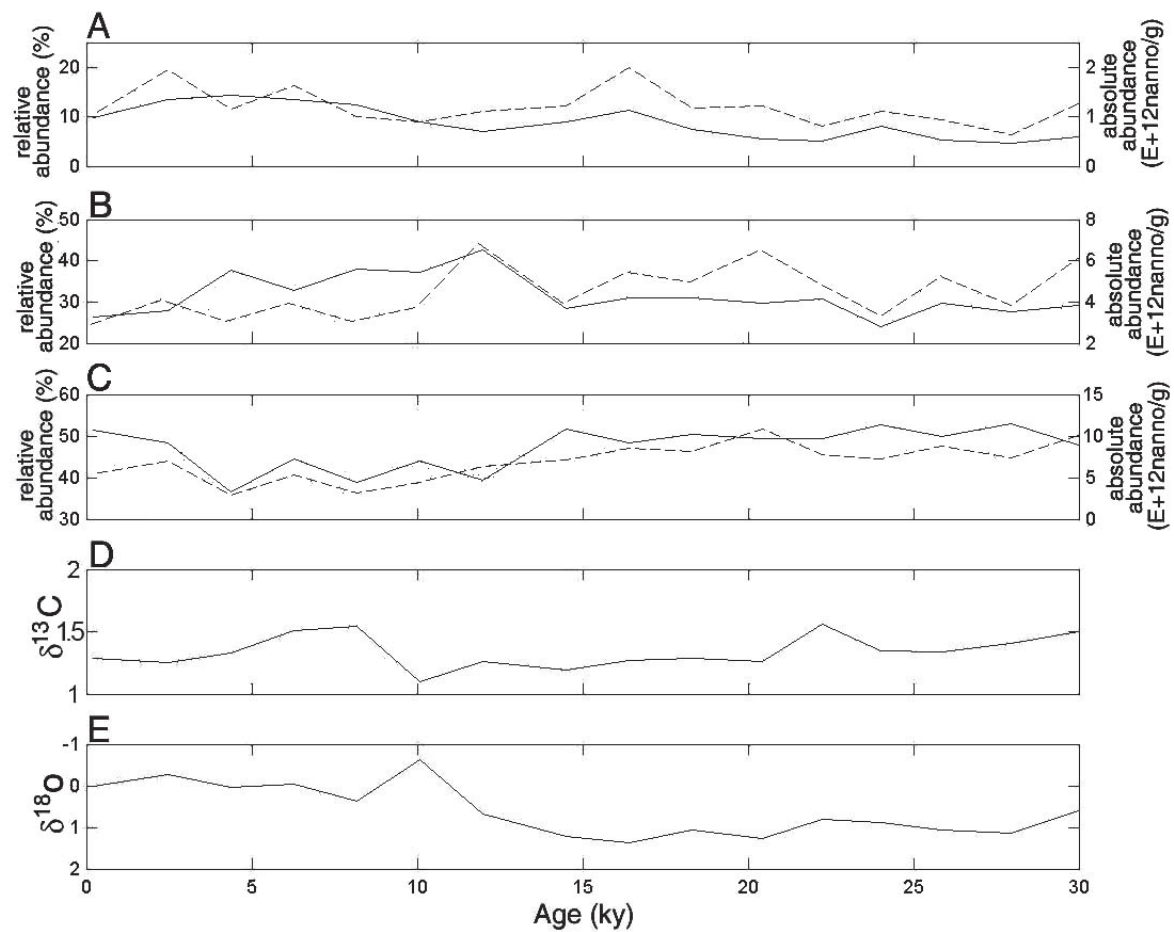

Figure 2. Relative (continuous lines) and absolute (dashed lines) abundances. A, Emiliania huxleyi; B, Gephyrocapsa sp.; C, Florisphaera profunda; and oxygen (D) and carbon isotope (E) records.

\section{Quantitative analyses}

In order to estimate absolute and relative abundance of calcareous nannofossils, the 16 slides were examined using an Olympus BX-41 light microscope under cross-polarized and transmitted light at $600 \mathrm{x}$ and $1000 \mathrm{x}$ magnification. Quantitative analyses were performed by counting at least 300 specimens in random fields of view (Okada, 1992; Roth, 1994).

The relative abundance was determined in each sample. Although relative abundance gives indications of alterations in dominance of different species in the assemblages it contains very little information about the absolute numbers of specimens of these species in the group (Henriksson, 2000). The fixed sum constraint on percentage data has an effect on the relative abundance data, i.e., if one species increases, others must decrease.

Absolute abundance (AA) of nannofossils expressed in number of specimens per gram of sediments (nanno/g) was then estimated using the following formula:

$$
\mathbf{A A}=\mathbf{n} \times\left(\mathbf{V} / \mathbf{V}_{\mathrm{p}}\right) \times\left(\mathbf{P}_{\mathrm{a}} / \mathrm{A}_{\mathrm{o}}\right) \times \mathbf{1} / \mathbf{W},
$$

where $\mathbf{n}=$ number of specimens counted, $\mathbf{V}=$ volume of water added to the dry sediment $(10 \mathrm{ml}), \mathbf{V}_{\mathbf{p}}=$ volume dropped onto the Petri disk, $\mathbf{P}_{\mathbf{a}}=$ area of the Petri disk, $\mathbf{A}_{\mathbf{o}}=$ area of one fields of view, and $\mathbf{W}=$ weight of sediments (Flores \& Sierro, 1997).

\section{RESULTS}

Relative abundances of calcareous nannofossil species obtained are reported in Table 2. Nannofossil absolute abundances estimated by random settling technique are presented in Table 3.

According to AMS dating and oxygen isotopes, the samples comprise the Marine Isotopic Stages (MIS) 1, 2 and 3. MIS 2 comprises Last Maximum Glacial (23-19 kyr) (Mix et al., 2001). The absolute and relative abundances of all 11 species observed and counted vary throughout the core.

Florisphaera profunda is the most abundant calcareous nannofossil species. The relative abundance ranges from $36.57 \%$ to $52.92 \%$ (mean $44.74 \%$ ), and the absolute abundance varies from $2.94 \times 10^{12}$ to $1.08 \times 10^{13}$ nanno/g (Figure 2B).

The second most frequent species is Gephyrocapsa $\mathrm{sp}$. ( $23.90 \%$ to $42.52 \%$, mean $33.2 \% ; 2.82 \times 10^{12}$ to $6.85 \times 10^{12}$ nanno/g) (Figure 2C). It is followed by Emiliania huxleyi which ranges from $4.56 \%$ to $14.34 \%$ (mean $9.45 \%$ ) in relative abundance and from $6.36 \times 10^{11}$ to $1.99 \times 10^{12}$ nanno/g in absolute abundance (Figure 2A).

The other subordinate species observed represent less than $10 \%$ of total calcareous nannofossil assemblages. Those species representing less than $6 \%$ reach a maximum $1.00 \mathrm{x}$ $10^{12}$ nanno/g.

The major absolute and relative abundance of $F$. profunda during MIS 2 and 3 and a drop in its values in MIS 1 contrasts with Gephyrocapsa sp. relative abundance behaviour, which tends to be pronounced all throughout MIS 1 and reduced during MIS 2 and 3. On the other hand, its absolute abundance is slightly higher in MIS 2 and 3 than in MIS 1.

There is an opposite behaviour in abundance between $F$. profunda and Gephyrocapsa throughout the core. These variations clearly characterize the Pleistocene/Holocene boundary (MIS 2-1) at $12 \mathrm{kyr}(37 \mathrm{~cm})$ and MIS 3-2 at 22kyr (70 
Table 2. Relative abundances of calcareous nannofossils species in Core ESP-8.

\begin{tabular}{|c|c|c|c|c|c|c|c|c|c|c|c|c|}
\hline 岳 & 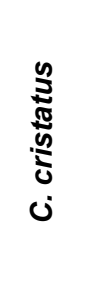 & 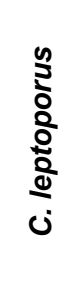 & 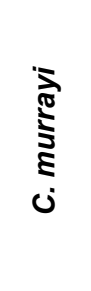 & 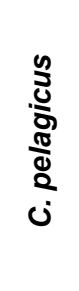 & 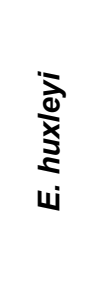 & \begin{tabular}{l}
$\frac{\pi}{2}$ \\
\multirow{5}{5}{} \\
$\frac{0}{2}$ \\
4
\end{tabular} & 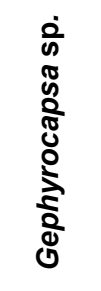 & 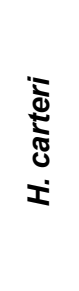 & 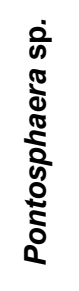 & $\begin{array}{l}\frac{\pi}{d} \\
\frac{D}{2} \\
\frac{\pi}{0} \\
\mathbb{0}\end{array}$ & 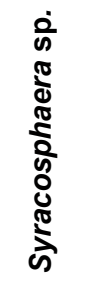 & 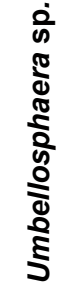 \\
\hline 0 & 0.31 & 0.61 & 0.77 & 0.00 & 9.83 & 51.46 & 26.42 & 2.00 & 0.00 & 2.46 & 1.84 & 2.30 \\
\hline 7 & 0.00 & 0.32 & 0.32 & 0.00 & 1.41 & 48.26 & 27.92 & 0.79 & 0.00 & 0.47 & 2.37 & 2.37 \\
\hline 13 & 0.20 & 1.41 & 0.00 & 0.00 & 14.34 & 36.57 & 37.78 & 2.02 & 0.00 & 1.01 & 2.83 & 1.21 \\
\hline 19 & 0.18 & 0.73 & 0.73 & 0.00 & 13.53 & 44.42 & 32.91 & 0.91 & 0.00 & 0.37 & 1.83 & 1.83 \\
\hline 25 & 0.00 & 1.34 & 0.76 & 0.00 & 12.43 & 38.81 & 38.05 & 2.29 & 0.00 & 1.34 & 1.53 & 1.72 \\
\hline 31 & 0.18 & 1.43 & 0.71 & 0.00 & 8.91 & 43.85 & 37.08 & 1.07 & 0.18 & 1.43 & 2.50 & 2.14 \\
\hline 37 & 0.00 & 0.66 & 1.33 & 0.00 & 6.98 & 39.37 & 42.52 & 1.50 & 0.00 & 1.83 & 2.49 & 1.83 \\
\hline 45 & 0.16 & 0.31 & 1.09 & 0.00 & 8.84 & 51.63 & 28.53 & 1.40 & 0.47 & 1.86 & 2.17 & 1.86 \\
\hline 51 & 0.00 & 1.30 & 1.13 & 0.00 & 11.35 & 48.30 & 30.96 & 0.97 & 0.00 & 1.62 & 2.76 & 0.97 \\
\hline 57 & 0.16 & 0.94 & 1.10 & 0.00 & 7.36 & 50.39 & 30.99 & 1.10 & 0.16 & 1.25 & 4.38 & 0.47 \\
\hline 64 & 0.29 & 1.45 & 1.89 & 0.00 & 5.52 & 49.27 & 29.65 & 1.45 & 0.58 & 1.74 & 4.07 & 1.02 \\
\hline 70 & 0.65 & 0.49 & 1.47 & 0.00 & 5.06 & 49.27 & 30.67 & 2.45 & 0.65 & 2.12 & 5.06 & 0.16 \\
\hline 76 & 0.00 & 1.66 & 1.36 & 0.00 & 8.02 & 52.80 & 23.90 & 1.66 & 0.15 & 1.97 & 5.14 & 1.36 \\
\hline 82 & 0.16 & 1.93 & 1.28 & 0.00 & 5.30 & 49.76 & 29.70 & 1.12 & 0.16 & 2.57 & 5.62 & 0.96 \\
\hline 89 & 0.00 & 1.85 & 1.57 & 0.00 & 4.56 & 52.92 & 27.53 & 1.85 & 0.29 & 2.00 & 3.71 & 1.43 \\
\hline 99 & 0.00 & 3.00 & 1.74 & 0.00 & 6.00 & 47.71 & 29.07 & 1.74 & 0.00 & 2.21 & 4.74 & 1.74 \\
\hline
\end{tabular}

$\mathrm{cm})$. However, their absolute abundances show the same trend along the core (Figure 2B, C). At 12kyr, both F. profunda and Gephyrocapsa sp. show a marked decline in absolute abundance.

In a general view, comparing quantitative data with the isotopic data provides two situations: (i) most calcareous nannofossils observed are in opposition to the oxygen isotope curve throughout the core, and (ii) the bulk of the species are in agreement with the carbon isotope curve during MIS 2 and 3, but are discordant during MIS 1. The only exception is Gephyrocapsa sp., of which the relative abundance slightly agrees with the oxygen and carbon isotopic curves along the whole core (Figures 2B, D, E).

\section{DISCUSSION}

Down-core abundances of calcareous nannofossil suggest a different climatic regime response during the last 30 kyr. Relative and absolute abundances of different species vary wildly throughout the core following variations in productivity and temperature. Most taxa have a decrease in abundance from MIS 3 to 1 , which strongly characterizes the transition from glacial to interglacial conditions.

Glacial temperatures are supposed to be colder $\left(\sim 2-3{ }^{\circ} \mathrm{C}\right)$ at the location of the core (Toledo, 2000; Costa, 2000). Glacial intervals are known to be more productive than interglacial ones due to strong seasonal contrast, wind strengthening and consequent upwelling intensification globally (Bradley, 1999; Henriksson, 2000). The different environmental conditions result in distinct nannofloral compositions between MIS 3-2 and 1, with marked changes in absolute and relative abundances. E. huxleyi and Umbellosphaera sp. clearly increase while all the other species decrease.

All species contributing to the MIS 1 assemblages are also present during glacials, although relative and absolute abundances vary. Pronounced variations in relative abundance of lower photic zone dweller, F. profunda (Okada, 1983, 1992) has been shown to reflect variations in the nutricline (and thermocline) depth (Molfino \& McIntyre, 1990) and productivity fluctuations (Beaufort et al., 1997; Henriksson, 2000). High relative abundance of $F$. profunda indicates low productivity with a deep nutricline, which means a nutrient-depleted upper photic zone. Except for F. profunda, all other species are considered to live mainly in the upper photic zone. The decrease of $F$. profunda relative abundance in the sample can reveal changes in the transparency of superficial waters, since the species depends on sun light for its development. Ahagon (1993) observed that there is a good correlation between the abundance of $F$. profunda and the transparency of the water column, in the present, in the northeast Pacific Ocean. In regions of great water transparency, F. profunda occurs abundantly. In open ocean, the transparency is greatly influenced by the primary production of superficial waters.

Absolute abundance of Gephyrocapsa sp. decreases from MIS 1 to MIS 2, suggesting the decrease of surface water productivity. On the other hand, relative abundance of this 
Table 3. Number of nannoliths per gram of sediment of calcareous nannofossils species in Core ESP-8.

\begin{tabular}{|c|c|c|c|c|c|c|c|c|c|c|c|c|}
\hline 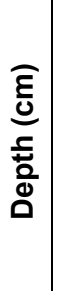 & 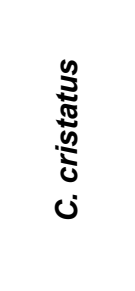 & 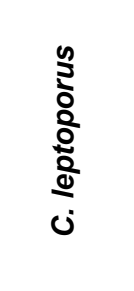 & 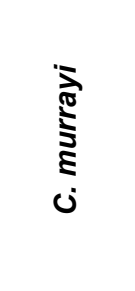 & 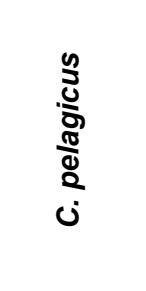 & 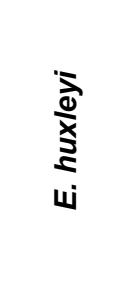 & \begin{tabular}{l}
$\frac{\pi}{2}$ \\
\multirow{5}{5}{} \\
$\frac{0}{2}$ \\
4
\end{tabular} & 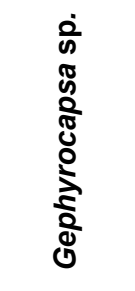 & 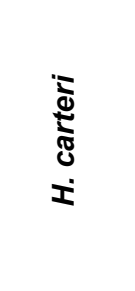 & $\begin{array}{l}\frac{0}{0} \\
\frac{0}{0} \\
0 \\
\frac{0}{0} \\
\frac{0}{0} \\
0 \\
0 \\
0 \\
0 \\
0\end{array}$ & $\begin{array}{l}\frac{\pi}{0} \\
\frac{\pi}{0} \\
\frac{\pi}{0} \\
\alpha\end{array}$ & 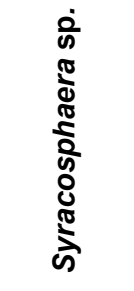 & 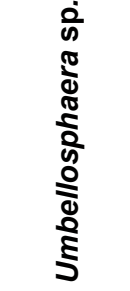 \\
\hline 0 & $28 \mathrm{E}+10$ & $6.56 \mathrm{E}+10$ & $20 \mathrm{E}+$ & $.00 E+00$ & $05 E+12$ & $50 \mathrm{E}+12$ & $2.82 \mathrm{E}+12$ & $2.13 E+11$ & $.00 \mathrm{E}+00$ & $2.63 E+11$ & $1.97 \mathrm{E}+11$ & $2.46 \mathrm{E}+11$ \\
\hline 7 & 年 & (1) & (10 & 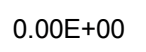 & $95 \mathrm{E}+12$ & $7.03 E+12$ & $4.07 \mathrm{E}+12$ & $15 E+11$ & $.00 \mathrm{E}+00$ & $89 E+10$ & $3.45 E+11$ & $3.45 E+11$ \\
\hline 13 & $62 \mathrm{E}+10$ & $14 \mathrm{E}+11$ & $00 \mathrm{E}+00$ & $0.00 E+00$ & $15 E+12$ & $2.94 \mathrm{E}+12$ & $3.04 \mathrm{E}+12$ & $62 \mathrm{E}+11$ & $.00 \mathrm{E}+00$ & $8.12 \mathrm{E}+10$ & $2.27 \mathrm{E}+11$ & $9.75 E+10$ \\
\hline 19 & 0 & 0 & $8.79 E+10$ & $0.00 \mathrm{E}+00$ & $3 E+12$ & 2 & 12 & 1 & $.00 \mathrm{E}+00$ & $4.39 \mathrm{E}+10$ & $2.20 \mathrm{E}+11$ & $2.20 \mathrm{E}+11$ \\
\hline 25 & $00 \mathrm{E}+00$ & .0OE+ 11 & $14 L+10$ & (5) & $.98 \mathrm{E}+11$ & -12 & $3.06 \mathrm{E}+12$ & $1.84 \mathrm{E}+11$ & $.00 \mathrm{E}+00$ & $1.08 \mathrm{E}+11$ & $1.23 \mathrm{E}+11$ & $1.38 \mathrm{E}+11$ \\
\hline & $80 \mathrm{E}+10$ & $.44 \mathrm{E}+11$ & $7.18 \mathrm{E}+10$ & $.00 \mathrm{E}+00$ & $.98 \mathrm{E}+11$ & $4.42 \mathrm{E}+12$ & $3.74 \mathrm{E}+12$ & $1.08 \mathrm{E}+11$ & $1.80 \mathrm{E}+10$ & $1.44 \mathrm{E}+11$ & $2.51 \mathrm{E}+11$ & $2.15 \mathrm{E}+11$ \\
\hline 37 & 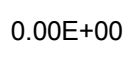 & $1.07 \mathrm{E}+11$ & $2.14 \mathrm{E}+11$ & $0.00 \mathrm{E}+00$ & $2 \mathrm{E}+12$ & & 2 & 1 & & $2.94 \mathrm{E}+11$ & & 2.0 \\
\hline 15 & 2. $13 \mathrm{E}+10$ & $4.27 \mathrm{E}+10$ & $1.49 \mathrm{E}+11$ & $0.00 \mathrm{E}+00$ & $.22 \mathrm{E}+12$ & $7.10 \mathrm{E}+12$ & $3.92 \mathrm{E}+12$ & $1.92 \mathrm{E}+11$ & $6.40 \mathrm{E}+10$ & $2.56 \mathrm{E}+11$ & $2.99 \mathrm{E}+11$ & $2.56 \mathrm{E}+11$ \\
\hline & $00 \mathrm{E}+00$ & $27 E+11$ & $99 \mathrm{E}+11$ & 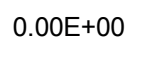 & $99 \mathrm{E}+12$ & $47 E+12$ & $5.43 \mathrm{E}+12$ & $1.71 \mathrm{E}+11$ & $.00 \mathrm{E}+00$ & $2.84 \mathrm{E}+11$ & $4.83 \mathrm{E}+11$ & $F+11$ \\
\hline 57 & $51 \mathrm{E}+10$ & $1.51 \mathrm{E}+11$ & $1.76 \mathrm{E}+11$ & 0.4 & $18 \mathrm{E}+12$ & $8.08 E+12$ & +12 & 11 & +10 & +11 & & $7.53 E+10$ \\
\hline 64 & $6.39 \mathrm{E}+10$ & $3.19 E+11$ & $4.15 \mathrm{E}+11$ & 6.006 & $1.21 \mathrm{E}+12$ & $1.08 E+13$ & $6.52 \mathrm{E}+12$ & $3.19 \mathrm{E}+11$ & $1.28 \mathrm{E}+11$ & $3.83 E+11$ & $8.95 E+11$ & $2.24 \mathrm{E}+11$ \\
\hline 70 & $04 \mathrm{E}+11$ & $6 \mathrm{E}+10$ & $5+1$ & $0.00 \mathrm{E}+00$ & $2 \mathrm{E}+11$ & $2 \mathrm{E}+12$ & +12 & $38 \mathrm{E}+11$ & $1.04 \mathrm{E}+11$ & $3.36 \mathrm{E}+11$ & $8.02 E+11$ & $2.59 \mathrm{E}+10$ \\
\hline 76 & $0.00 \mathrm{E}+00$ & $2.30 \mathrm{E}+11$ & $1.88 \mathrm{E}+11$ & $0.00 E+00$ & $.11 \mathrm{E}+12$ & $7.30 \mathrm{E}+12$ & $3.31 \mathrm{E}+12$ & $2.30 E+11$ & $2.09 \mathrm{E}+10$ & $2.72 E+11$ & $7.11 \mathrm{E}+11$ & $1.88 \mathrm{E}+11$ \\
\hline . & $2.82 \mathrm{E}+10$ & $3.38 \mathrm{E}+11$ & 2.205 .11 & & $9.29 \mathrm{E}+11$ & $8.73 E+12$ & $5.21 \mathrm{E}+12$ & $1.97 \mathrm{E}+11$ & $2.82 \mathrm{E}+10$ & $4.51 \mathrm{E}+11$ & $9.86 \mathrm{E}+11$ & $1.69 E+11$ \\
\hline 89 & $.00 \mathrm{E}+00$ & $8 \mathrm{E}+11$ & $19 \mathrm{E}+11$ & $00 \mathrm{E}+0$ & $36 \mathrm{E}+11$ & 7.37E+12 & $3.84 \mathrm{E}+12$ & $.58 \mathrm{E}+11$ & $3.98 \mathrm{E}+10$ & $2.78 \mathrm{E}+11$ & $5.17 \mathrm{E}+11$ & $1.99 \mathrm{E}+1$ \\
\hline & $0.00 \mathrm{E}+00$ & $6.36 \mathrm{E}+11$ & $0.00 \mathrm{~L} \cdot 1$ & $0.00 \mathrm{E}+00$ & $.27 \mathrm{E}+12$ & $1.01 \mathrm{E}+13$ & $6.16 \mathrm{E}+12$ & $3.68 \mathrm{E}+11$ & $0.00 \mathrm{E}+00$ & $4.69 \mathrm{E}+11$ & $1.00 \mathrm{E}+12$ & $0.00 \mathrm{~L}$ \\
\hline
\end{tabular}

species increases as relative abundance of $F$. profunda decreases, suggesting a higher productivity in superficial waters associated to the ascent of thermocline and nutricline. It is clear that productivity is higher during MIS 2 than during MIS 1, which is supported by the carbon isotopic record and total abundances. Although the relationship between the relative abundances of Gephyrocapsa sp. and F. profunda is apparently indicating a deeper nutricline and thermocline during MIS 1, the productivity of superficial waters is lower in this period.

There is an increase in Gephyrocapsa sp. relative abundance between 12-10 kyr. Similar trends were observed in the absolute and relative abundance of E. huxleyi and Umbellosphaera sp., which suggests high productive surface waters corroborated by carbon isotopic data. For most species of calcareous nannofossil assemblages we have found similar results to the ones of Gephyrocapsa sp., though there is a slight deviation between relative and absolute abundances of this species during MIS 1. In view of that, we speculate a deeper nutricline and thermocline, hence less productive surface waters during MIS 1 than during MIS 2 and 3.

Absolute abundances and relative abundances point to conflicting conclusions. The introduction of absolute abundances in the study showed to be very important since these data seem to be directly correlated to productivity.

The traditional techniques produce thicker slides than those by random settling. "Surprisingly" this thickness could make counting procedure difficult and time-consuming. This is because preparation of consistently well-spread slides for nannofossil counting is arbitrary. For that reason, frequently, many fields of view hard to achieve under light microscope must be counted in real-life work.

\section{CONCLUSIONS}

The use of quantitative studies of certain calcareous nannofossils taxa with isotopic carbon data demonstrated to be useful for the evaluation of the productivity of the superficial ocean. Down-core abundances of calcareous nannofossils suggest a different climatic regime response during the last 30 kyr. The absolute abundances of Gephyrocapsa sp. confirmed the carbon isotope record, indicating higher productivity during MIS 2 than during MIS 1.

The random settling technique displays a data that other techniques do not, the absolute abundance. This one demonstrated to be very important in quantitative studies, since it gives us support to infer mainly about productivity.

Additionally, this procedure produces homogeneous, welldistributed slides, which help species identification as well as quantitative analyses. Moreover, it allows a derivation of both relative and absolute abundances, both recognized as useful paleoceanographic tools especially when combined with isotopic datasets. These results can help better understand paleoproductivity variations due to climate and environmental changes. 


\section{ACKNOWLEDGMENTS}

We thank Maria A. G. Pivel for providing important insights and advice for this research. This work was financially supported by Fundação de Amparo à Pesquisa do Estado de São Paulo (process 04/02819-8). We thank Petrobras for providing the samples. This is Laboratório de Paleoceanografia do Atlântico Sul (LaPAS) contribution number 11 .

\section{REFERENCES}

Ahagon, N.; Tanaka, Y \& Julie, H. 1993. Florisphaera profunda, a possible nannoplankton indicator of late Quaternary changes in sea-water turbidity at the northeast margin of the Pacific. Marine Micropaleontology, 22:255-73.

Antunes, R.L. 1997. Introdução ao estudo dos nanofósseis calcários. Rio de Janeiro, UFRJ, 115 p.

Baretta-Bekker, J.G.; Duursma, E.K. \& Kuipers, B.R. 1998. Encyclopedia of Marine Sciences. New York, Springer, 357 p.

Beaufort, L.; Lancelot, Y.; Camberlin, P.; Cayre, O.; Vincent, E.; Bassinot, F. \& Labeyrie, L. 1997. Insolation cycles as a major control of equatorial Indian Ocean primary production. Science, 278:1451-1454.

Bradley, R.S. 1999. Marine sediments and corals. In: R.S. Bradley (ed.) Paleoclimatology-reconstructing climates of the Quaternary. Elsevier, p. 191-283.

Buccheri, G.; Capretto, G.; Di Donato, V.; Espósito, P.; Ferruzza, G.; Pascatore, T.; Russo, E.; Senatore, M.R.; Sprovieri, M.; Bertoldo, M.; Carella, D. \& Madonia, G. 2002. A high resolution record of the last deglaciation in the southern Tyrrhenian Sea: environmental and climatic evolution. Marine Geology, 186:447470.

Buccianti, A. \& Esposito, P. 2004. Insights into Late Quaternary calcareous nannoplankton assemblages under the theory of statistical analysis for compositional data. Palaeogeography, Palaeoclimatology, Palaeoecology, 202: 209-227.

Costa, K.B. 2000. Variações paleoceanográficas na porção Oeste do Atlantico Sul entre o último máximo glacial e o Holoceno: isótopos estáveis de Oxigênio e Carbono e razão $\mathrm{Cd} / \mathrm{Ca}$ em foraminiferos bentônicos. Programa de Pós-graduação em Geociências, Universidade Federal do Rio Grande do Sul, Doctoral Dissertation, $250 \mathrm{p}$.

Ferreira, J. \& Cachão, M. 2003. Nanofósseis calcários em fácies costeiras: revisão de técnicas de estudo. Ciências da Terra (UNL), special volume V, CD-ROM:A76-A78.

Flores, J.A. \& Sierro, F.J. 1997. Revised technique for calculation of calcareous nannofossil accumulation rates. Micropaleontology, 43:321-324.

Giraudeau, J. 1992. Coccolith paleotemperature and paleosalinity estimates in the Caribbean Sea for the middle-late Pleistocene (DSDP Leg 68-Hole 502B). Memorie di Scienze Geologiche, 43:375-387.

Henriksson, A.S. 2000. Coccolithophore response to oceanographic changes in the equatorial Atlantic during the last 200,000 years. Palaeogeography, Palaeoclimatology, Palaeoecology, 156:161173.
Herrle, J.O. 2003. Reconstructing nutricline dynamics of midCretaceous oceans: evidence from calcareous nannofossils from the Niveau Paquier black shale (SE France). Marine Micropaleontology, 47:307-321.

Martinson, D.G.; Pisias, N.G.; Hays, J.D.; Imbrie, J.T.C.; Moore J. \& Shackleton, N.J., 1987. Age dating and the Orbital Theory of the Ice Ages: development of a high-resolution 0 to 300,000year chronostratigraphy. Quaternary Research, 27:1-29.

Matsuoka, H. \& Okada, H. 1989. Quantitative analysis of Quaternary nannoplankton in the subtropical north western Pacific Ocean. Marine Micropaleontology, 14:97-118.

McIntyre, K. \& Bé, A.W.H. 1967. Modern Coccolithophoridae in the Atlantic Ocean. I: Placoliths and Crytholiths. Deep-Sea Research, 14:561-597.

Mix, A.C., Bard, E. \& Schneider, R. 2001. Environmental processes of the Ice Age: land, oceans, glaciers (EPILOG). Quaternary Science Reviews, 20:627-657.

Molfino, B. \& McIntyre, A. 1990. Precessional forcing of nutricline dynamics in the Equatorial Atlantic. Science, 249:766-769.

Mostajo, E.L. 1986. Estudio de dos testigos submarinos del oceano Pacífico Sudecuatorial. Revista Española de Micropaleontología, 18(3):433-442.

Okada, H. 2000. Neogene and Quaternary calcareous nannofossils from the Blake Ridge, sites 994, 995 and 997. Proceedings of the Ocean Drilling Program, Scientific Results, 164:331-341.

Okada, H. 1992. Biogeographic control of modern nannofossil assemblages in surface sediments of Ise Bay, Mikawa Bay e Kumano-Nada, off coast of central Japan. Memorie di Scienze Geologiche, 43:431-449.

Okada, H. 1983. Modern nannofossil assemblages in sediments os coastal and marginal seas along the western Pacific Ocean. Utrecht Micropaleontology Bulletin, 30:171-187.

Okada, H. \& Honjo, S. 1973. The distribution of oceanic coccolithophorids in the Pacific. Deep-Sea Research, 20:355374.

Roth, P. 1994. Distribution of coccoliths in oceanic sediments. In: A. Winter \& W. Siesser (eds.) Coccolithophores, Cambridge University Press, p. 199-218.

Steinmetz, J.C. 1994. Stable isotopes in modern coccolithophores. In: A. Winter \& W. Siesser (eds.) Coccolithophores, Cambrige University Press, p. 219-229.

Thierstein, H.R.; Geitzenauer, K.R.; Molfino, B. \& Shackleton, N.J. 1977. Global synchroneity of late Quaternary coccolith datum levels: validation by oxygen isotopes. Geology, 5:400404.

Toledo, F.A.L. 2000. Variações paleoceanográficas nos últimos 30.000 anos no oeste do Atlântico Sul: isótopos de oxigênio, assembléias de foraminíferos planctônicos e nanofósseis calcários. Programa de Pós-graduação em Geociências, Universidade Federal do Rio Grande do Sul, Doctoral Dissertation, $245 \mathrm{p}$.

Winter. A.; Jordan, R.W. \& Roth, P.H. 1994. Biogeography of the living coccolithophores in ocean waters. In: A. Winter \& W. Siesser (eds.) Coccolithophores. Cambrige University Press, p. 161-179.

Young, J.R. 1991. A Quaternary nannofossil range chart. International Nannoplankton Association Newsletter, 13:14-17. 